\title{
50. Devonian-Carboniferous Boundary in Japan
}

\author{
By Hisakatsu YABE, M.J.A. \\ (Comm. April 12, 1958)
}

The Devonian formations palaeontologically proved are very limited in distribution, being now known from only four districts: one in each of the Hida and Abukuma Mountainlands, and two in the Kitakami Mountainland.

The Takaharagawa formation of the Hukuzi district, Hida Mountainland, consists of sandy shale intercalating limestone lenses, and entombing corals, brachiopods and trilobites (Cheirurus (Crotalocephalus) japonicus Kobayashi and Igô, C. (C.) sp.). Being in fault contact with the Carboniferous Itinotani limestone, the DevonianCarboniferous boundary is exposed nowhere (T. Kobayashi and H. Igô, 1956).

The Ainosawa formation of the Sôma district in the Abukuma Mountainland consists mostly of gray hard shale and porphyritic tuff intercalating purplish and greenish slates; more than $70 \mathrm{~m}$ thick. It is late Devonian in age according to I. Hayasaka and M. Minato who described the following fossils (I. Hayasaka and M. Minato, 1954).

Sinospirifer sinensis var. australis Maxwell

Cyrtospirifer sp.

Camarotoechia sp.

Chonetes sp.

The Ainosawa formation rests unconformably on the Matugadaira. The latter is stated by T. Sato to chiefly consist of "greenish phyllite and greenish sandstone with abundant quartz veins; schistosity remarkably developed locally; schalstein, liparitic, and andesitic tuffs occur in various horizons. About $500 \mathrm{~m}$ thick. Presumably Devonian-Gotlandian or older". The stratigraphical break between these two formations is significant.

The "Geological map of the Kamimanomura region" of Sato (1956, Fig. 2) shows a syncline trending $\mathrm{N}-\mathrm{S}$ of the Matugadaira, Ainosawa and several Carboniferous and Permian formations; it is stratigraphically asymmetrical, the Ainosawa being exposed only in a narrow belt of its east wing between the Matugadaira and Uwagaya formations. Where the Ainosawa is missing, the Matugadaira is directly overlain by the Mano formation, next younger than the Ainosawa.

The Mano is a formation, $150 \mathrm{~m}$ thick, of sandstone and slate in thin-bedded alternation with many brachiopods, simple corals, and a few trilobites. These fossils are not fully studied, but Sato believes 
the Lower Carboniferous age of the fossil fauna.

The Mano formation is unconformable with the overlying Tateisi with a coral fauna of Late Viséan age. Sato who has given details about this unconformity and that between the Mano and the Matugadaira, simply mentioned the unconformity between the Mano and Ainosawa formations, without any further comments (T. Sato, 1956). The stratigraphical relation of the last mentioned two formations is not readable on his geological map, because they are almost separated in their areal distribution.

All that can be now inferred are, 1, the stratigraphical relation between the Ainosawa and Matugadaira formations is almost similar to that between the Mano and Matugadaira, and 2, the stratigraphical relation between the Mano and Ainosawa is more intimate than the others cited above.

Devonian rocks are better developed in the Kitakami Mountainland. They occupy two separate areas, one in the Hikoroiti district and the other in the Nagasaka district. In the former district, they are overlain unconformably by the Lower Carboniferous Hikoroiti formation (M. Okubo, 1951a) and grouped into three formations, namely, in descending order:

Ômori formation, $250 \mathrm{~m}$. Black slate and schalstein in alternation, with a thick, coarse-grained or pebbly sandstone at the base; rare in fossils. Phacops was once recorded from it. Conformable to the lower formation.

Nakazato formation, 500-530 m. A $100 \mathrm{~m}$ thick schalstein, partly lava-agglomerate, at the base; succeeded upward by black slate and schalstein in alternation; rarely thin limestone lenses interbedded. Very fossiliferous in a horizon in the upper part (Phacops zone); fossils described by M. Okubo are (M. Okubo, 1951b, 1956):

Stropheodonta cymbiformis Swallow

Str. boonensis Swallow

Meristella sp.

Camarotoechia tethys (Billings)

Atrypa pauciplicata Okubo

Anoplotheca dorsosulcata Okubo

An. umbonata (Conrad)

Cyrtina heteroclyta Defrance

Spirifer cf. speciosus (Schlotheim)

Elytha fimbriatas (Conrad)

Phacops nonakai Okubo

Dechenella minima Okubo

Thysanopeltis paucispinosa Okubo 
Middle Devonian; Eifelian after Y. Onuki. A slight unconformity has been recognized by Onuki between this and the next lower formation.

Ôno formation, $320 \mathrm{~m}$. Dark green to green siliceous slate, schalstein, and tuffaceous sandstone in alternation; subangular granite pebbles often found in the schalstein at the base, which is also interbedded with granite-sandstone. A limestone lense at $40-60 \mathrm{~m}$ above the base is rich in fossils (Thamnopora zone). Favosites spp., Thamnopora, Pachypora, Alveolites, Coenites, Heliolites, Prismatophyllum, Spongophyllum, Tryplasma, Cymatelasma, Actinostroma, etc.

This fauna is not yet fully studied; probably Lower Devonian.

The geological age of the Ômori formation is unsettled owing to its scanty fossils. However, stratigraphically its Upper Devonian or upper Middle Devonian age is convincing. It is so far certain that the Ômori formation is younger than the Nakazato of Middle Devonian age and older than the overlying Hikoroiti of Etroeungtian-Tournaisian age.

Special attention should be given to that the Sinospirifer horizon is not yet found in the Hikoroiti district, despite its occurrence in the Sôma district in the Abukuma Mountainland as stated above, and in an equivalent deposit in the Nagasaka district to be mentioned below.

The Nagasaka district is the second area of Devonian rocks in the Kitakami Mountainland, where M. Noda discovered "Spirifer verneuili" and several other brachiopods of the Upper Devonian or Lowest Carboniferous types in his Tobigamori formation and made first known the Devonian rocks in Japan. Lately, K. Tachibana separated the Tobigamori of Noda into two formations, the lower, Nakakura formation and the upper, Karamatudate; he found in the lower division, Leptophloem cf. australe (McCoy) and Cyclostigma sp. in association with the brachiopods cited above and in the upper fragmental remains of other Lepidophyta. Leptophloem does not exist in the upper division.

Karamatudate formation, $600 \mathrm{~m}$. Light green sandstone and a sandy shale prevailing; a conglomerate with chert pebbles at the base; rich in brachiopods and molluscs. Spirifer verneuili Murchison, Syringothyris cf. cuspidata Martin, Athyris lamellosa L'Eveillé, and many others cited by K. Tachibana, which need more critical studies. This formation is thought with right by Minato and others to be nearly equivalent to the Hikoroiti formation of the Hikoroiti district.

Nakakura formation, $800 \mathrm{~m}$. Mostly slate, repeatedly intercalating reddish tuffaceous shale and conglomerate; conglomerate characterized by having subangular pebbles of crystalline schists of 
various kinds, diabase, porphyrite, chert, sandstone, mylonite, etc. Fossiliferous; abundant brachiopods and molluses, including "Spirifer verneuili", Camarotoechia, Athyris, Chonetes, Leptaena, Productus, etc. Besides, Leptophloem cf. australe, and Cyclostigma occurring mixed with marine fossils.

Lately some of the brachiopods have been critically examined by Hayasaka and Minato who described:

Cyrtospirifer cf. kindlei Stainbrock

C. $\quad$ sp. $=$ Spirifer verneuili of Yabe and Noda

C. $\quad$ spp.

Camarotoechia sp.

Late Devonian

Stratigraphically and palaeontologically the two formations are intimately related, so as Noda once took them together as forming a single formation, his Tobigamori: if the two be really unconformable with each other, as now sometimes thought, then the unconformity may be very slight and an insignificant one. On the other hand, an important unconformity is inferred to exist between the hidden base of the Nakakura formation and the underlying basement which is also not exposed there, based on the nature of its sediments and sedimentary condition (H. Yabe and M. Noda, 1933; M. Noda, 1934; K. Tachibana, 1950, 1952, 1955; M. Minato, 1950; Y. Onuki, 1956; I. Hayasaka and M. Minato, 1954).

All the stratigraphical conditions reported from the Kitakami and Abukuma Mountainlands, outlined above, relating to the Devonian and Carboniferous deposits led the writer to the conclusion that an important major stratigraphical break may exist between the late Devonian formation with the Sinospirifer-Cyrtospirifer horizon and the earlier one (either early Upper Devonian or Middle Devonian), and not between the two formations palaeontologically equivalent to the late Devonian and early Carboniferous of the standard division.

\section{References}

I. Hayasaka and M. Minato (1954): A Sinospirifer faunule from the Abukuma Plateau northeast Japan, in comparison with the so-called Upper Devonian brachiopod faunule of the Kitakami Mountains, Trans. Proc. Pal. Soc. Japan, N. S., no. 16.

T. Kobayashi and H. Igô (1956): On the occurrence of Crotalocephalus, Devonian trilobites, in Hida, West Japan, Jap. Jour. Geol. Geogr., 27, nos. 2-4.

M. Minato (1950): Stratigraphische Stellung der Hikoroiti Series (Japanisch), Jour. Geol. Soc. Japan, 56, no. 655.

M. Noda (1934): Geological research in the region around Nagasaka, in the western part of the Kitakami Mountains (in Japanese), Jour. Geol. Soc. Japan, 41.

M. Okubo (1951a): Pre-Hikoroiti unconformity (in Japanese), Jour. Geol. Soc. Japan, 57, no. 669 . 
M. Okubo (1951b): Trilobites of Japan (in Japanese; with description of fossils in English), Earth Sci., no. 4.

- (1956): Some Devonian brachiopods and trilobites of the southern Kitakami Mountainland, Jap. Jour. Geol. Geogr., 27, no. 1.

Y. Onuki (1956): Geology of the Kitakami Massif (in Japanese).

T. Sato (1956): On the Tateishi formation and its Carboniferous coral fauna, in the northeastern part of the Abukuma Massif, Japan, Sci. Rep., Tokyo Kyoiku Daigaku, sec. C, no. 36 .

K. Tachibana (1950): Devonian plants first discovered in Japan, Proc. Japan Acad., 26, no. 9 .

— (1952): Tobigamori group of the Nagasaka district, Kitakami Mountainland (in Japanese), Jour. Geol. Soc. Japan, 58, nos. 683/684.

- (1955): Lepidophyta from the Nagasaka district, Kitakami Mountainland, Sci. Rep., Fac. Arts. Lit., no. 4.

H. Yabe and M. Noda (1933): Discovery of Spirifer verneuili Murchison in Japan, Proc. Imp. Acad., 9. 